\title{
Egypt's National Social Protection Response to Vulnerable Groups during COVID-19
}

\author{
Rihan Wu \\ Nanjing Sky Technology, Co. Ltd., Nanjing, China \\ Email: rihanwu0717@gmail.com
}

How to cite this paper: Wu, R. H. (2021) Egypt's National Social Protection Response to Vulnerable Groups during COVID-19. Open Journal of Social Sciences, 9, 143-152. https://doi.org/10.4236/jss.2021.99010

Received: August 5, 2021

Accepted: September 3, 2021

Published: September 6, 2021

Copyright $\odot 2021$ by author(s) and Scientific Research Publishing Inc. This work is licensed under the Creative Commons Attribution International License (CC BY 4.0).

http://creativecommons.org/licenses/by/4.0/ (c) (i) Open Access

\begin{abstract}
Since March 2020, the Coronavirus has widely spread in Egypt and negatively affected people's lives, especially the vulnerable groups. The government, private sectors, and social societies had played significant roles in supporting the needed groups to overcome the crisis. The present article has studied the Egyptian authorities' measures implemented to mitigate the pandemic's negative impact on the vulnerable groups-women, children, and informal workers. Confronting the sudden crisis, the Egyptian government swiftly responded the most by being the first country to empower women and financially support informal workers. However, some flaws appeared during operations as a result of poor infrastructure. We proposed some recommendations, for instance, increase transparency in Takaful and Karam Programme's operations and extend the coverage of the programme; prevent school drop-outs in child laborers, and build a complete informal workers' database that shall help reduce vulnerability and build resilience to future sudden shocks in Egypt.
\end{abstract}

\section{Keywords}

Egypt, COVID-19, Social Protection Responses, Vulnerable Groups

\section{Introduction}

Egypt in the pre-pandemic era had a huge population size, one-third of it is under the poverty line; by the beginning of 2020, the total Egyptian population reached over 102 million; this massive population growth has negatively impacted different venerable groups.

The informal workers present $63 \%$ of the total employed (around 30 million) in all sectors, contributing to $30 \%-40 \%$ of the GDP (Stephan, 2020). Nevertheless, there are many informal workers, which underlie minor social protection, like health insurance, paid vacations or unemployment grants, etcetera. 
Women are playing critical roles in supporting households and the growth of the whole country's economy. However, Egyptian women have faced plenty of bias and unfair treatment for decades, like domestic violence, sexual harassment, and workplace inequalities.

Egypt possesses one of the highest fertility rates, and its incomplete social protection system led to child poverty, child labor, early marriage, and homelessness. Regarding the child labor issue, in 2014, the World Food Programme and the European Union have reported that the number of child laborers had reached 2.7 million. Subsequently, the authorities announced that around 16,000 children were living in the street. In this regard, the UN Children Fund refuted that the actual number is much higher than the announced number by the Egyptian government.

Coronavirus swept down Egypt in March 2020, and its economy had been severely attacked since the second quarter of 2020 and has dramatically increased the unemployment rate and reduced the average family income. Egypt's unemployment rate in Q2 has jumped from 7.7\% in Q1 to 9.6\%, which is considered the highest in the past two years (Egypt Today, 2020b). The number of unemployed reached 2574 million, male and female unemployment rates increased to $8.5 \%$ and $16.2 \%$, respectively. On the other hand, the average family income decreased to around 405 EGP monthly, a decline of $6.2 \%$ (168 EGP) in the rural families' income, and 9.7\% (271 EGP) in the urban families' income (Clemens Breisinger et al., 2020).

The present article discussed the Egyptian government's social protection performance during this unprecedented crisis concerning women, children, and informal workers who tend to be vulnerable to sudden shocks.

\section{Overview of Egypt's Social Protection during COVID-19}

\subsection{Women}

Egypt was the first country in the region to empower women and protect them from the negative impact of COVID-19. Regarding the COVID-19 Global Gender Response Tracker, the Egyptian authority took 21 women-related measures, covered three aspects-economic security (7 measures), combating violence against women (11 measures), and unpaid care work (3 measures).

Economic Empowerment: 1) Cash transfer; During the pandemic, financial assistance channeled in a couple of ways. One is a pre-existing social protection programme, Takaful and Karama Programme; another is an emergency grant for irregular workers from the Ministry of Manpower. Egyptian government added more people to Takaful and Karama Programme as one of the responses to the pandemic. The Ministry of Social Solidarity has been operating the Takaful and Karama Programme since 2015 to transfer cash and other humanitarian aids to low households to improve their lives. Over $80 \%$ of recipients in Takaful and Karama are females. The Takaful (Solidarity) cash-support programme for lowincome families with children in school. The programme gives 425 LE monthly 
to each family in addition to $60 \mathrm{LE}$ for each child in primary school, $80 \mathrm{LE}$ for a child in preparatory school, and 100 LE for a child in high school. This support was exclusive for families with no more than two children in school and receiving education and healthcare regularly. The Karama (Dignity) programme targets the elderly, people with special needs, widows, and divorced women. The programme grants subscribers 450 LE per month (Mounir, 2020). According to the annual report of the Ministry of Social Solidarity, 411,000 new families have been added to the programme in 2020 and reached a total number of 3,413,006 families (15 million individuals) (State information service, 2021). However, certain data ambiguities among different government agencies, international organizations, and studies were discussed in the recommendation section. Additionally, some women were granted a 1500 EGP from the Ministry of Manpower to mitigate the negative impact of the pandemic. Moreover, the Egyptian authority raised the payment for women in the rural areas from 300 EGP to 900 EGP each month. 2) Support for women's entrepreneurship and employment; Besides one-off cash transferring urgent measures, the government also set long-term solutions for border and upper governorates' employment rates. The Micro, Small, and Medium Enterprises Development Agency (MSMEDA) allocated 5.4 billion EGP (343 million USD) to finance women-related projects. It is expected that 216,000 micro-projects will be implemented over five years, and 250,000 jobs and projects will be funded through banks and civil society organizations that cooperate with the agency (Egypt Independent, 2020). On the other hand, the government provided various training programmes to teach different professions to help them develop their skills and have better employment chances-for instance, online marketing. Also, the cooperation between government agencies and civil institutions to integrate and train women from different governorates to manufacture masks and marketing them.

Combating violence against women: Previously, it has been reported that approximately 7.8 million Egyptian women have experienced a particular type of violence and more than one-quarter (26 percent) of ever-married women had physical violence (International Finance Corporation, 2020). After the lockdown was implemented, the rate of sexual harassment and physical/mental abuse has rapidly increased-the government endorsed measures to guarantee women security against any forms of violence. First, set up a series of online and offline initiatives to raise public awareness of the importance of combating violence against women and protecting women's rights. Also, the government provided a hotline for women who encountered violence and sought help. Second, provided support to the survivors of domestic violence, the authorities offered online and offline psychosocial and legal aid to help violence-related post-traumatic women and girls.

Social Service: With the demands of multitasking working mothers, the Egyptian government had decreed orders to guarantee alleviation in accomplishing their different duties. In March 2020, the Egyptian prime minister launched a 
policy that gave exceptional leave to pregnant employees, nursing workers looking after children under 12 years old, and mothers with disabled children. The National Council for Women's provided a hotline to receive complaints and supported working mothers to ensure the decree works smoothly. Caring for women's mental health was another vital part that the government focused on during the pandemic. In May 2020, the National Council for Women collaborated with UN Women to support women's mental health initiative to raise public awareness about the importance of caring for mental health in this challenging time. The Egyptian government recently included women beneficiaries dominatingTakaful and Karama Programme to the free COVID-19 vaccine campaign.

\subsection{Children}

Since COVID-19 broke out, the previously discussed children's problems had not shown any positive changes but got more severe after the lockdown in the country. Other threats have emerged; for example, kids are directly exposed to inappropriate internet content, educational setbacks, pandemic threats, school drop-outs, child laborers, etcetera. The Egyptian authorities took action during the crisis to provide proper child protection. However, these measures haven't reached a decent threshold concerning children in need, like poor or homeless kids.

Distance Learning: In March 2020, the government closed the schools and turned toward online learning to prevent the spread of infection among students. Meanwhile, the government broadcasted educational televised lessons on [Our School, Egypt Educational Channel, Egypt Educational Channel Live, Egyptian Educational Channel 1, etcetera] exclusively for those with no access to smartphones or computers.

Moreover, the government uploaded all grades' curricula on the ministry of education platform, the digital library, and the Egyptian Knowledge Bank's website to facilitate students' study (Ahram Online, 2020). Additionally, all students were given free access to the online library to study during the lockdown time.

Homeless children: In early 2020, the Ministry of Social Solidarity increased the number of shelters to host more homeless children and adults. It also provided a hotline to the public and urged the citizens to provide information about any homeless personal who need assistance (Egypt Today, 2020c). COVID-19, alongside a fragile economy, has pushed street children to confront desperate conditions. Most homeless children survive by selling tissues, cotton candy, mints, and other small stuff, but their meager income source had been obstructed after the national lockdown. In this regard, in June 2020, the Atfal Bala ma'wa programme sent mobile units across the country to help street children hit hard by the crisis. The aids included food, medical treatment, psychological therapy, and others.

Safer internet environment: In Egypt, the numbers of teenage internet users are enormous. According to a previous study, about 12 million internet users are between 13 - 21 years old and increasing. After the lockdown of the schools, 
children have a significant amount of spare time to use their phones and computers. Thus, it was urgent to guarantee the proper internet environment for the young during their browsing. Nevertheless, the National Council for Childhood and Motherhood (NCCM) appealed to the public to raise awareness of internet security for children and provided a helpline for any queries.

\subsection{Informal Workers and Poor Households}

According to Central Agency for Public Mobilization and Statistics (CAPMAS), the pandemic badly affected around $61.9 \%$ of the irregular workers, and $20 \%$ have lost their jobs. Also, $41 \%$ can no longer afford their standard of living costs (Jr, 2021). At the beginning of 2021, the Minister of Social Solidarity declared that the COVID-19 pandemic turned many citizens living on the borderline of poverty into poor, according to the ministry's poverty definition (Egypt Independent, 2021). The Egyptian authority allocated emergency grants for informal workers and distributed humanitarian aids to poor households to mitigate the negative pandemic impact.

Cash transfer: At the end of March 2020, the Ministry of Manpower offered 1500 EGP as financial support for informal workers who had registered on the ministry's website (https://www.manpower.gov.eg/) and met the ministry's requirements. Subsequently, out of 2.5 million casual workers, only 1.6 million workers were eligible for the ministry's criteria and benefited from this cash support. Meanwhile, the government provided the hotline [142] to the workers to inquire about eligibility and cashing outlets. The government also started various training programmes for workers to obtain better job opportunities in parallel with cash transfer.

Humanitarian support: During the pandemic, Tahya Misr Fund (Long Live Egypt Fund) played a pivotal role in the delivery of humanitarian aid to the neediest families. Until June 2020, the fund allocated medicine bags to 550,000 families. Before August 2020, a total of 500,000 neediest families received food supplies from the fund. It delivered supplements including 7000 tons of food, 170 tones of meat, 150 tones of poultry, 160 tones of vegetables, and 300,000 sweet bars (Aees, 2020).

\section{Recommendations}

The data above has presented the measures that the Egyptian government made to protect vulnerable groups from the negative impact of the COVID-19 pandemic. However, there are still lots to be enhanced. We listed some of our recommendations to help the Egyptian authorities' more responsive measures during the unprecedented pandemic.

\subsection{Women}

1) More informative transparency regarding Takaful and Karama Programme. There were conflicting numbers that the Ministry of Social Solidarity has announced. They declared that by February 2020, there were 2.5 million 
families who benefited from Takaful and Karama programme (Egypt Today, 2020a), and by the end of December 2020, there were 3,413,006 beneficiaries from Takaful and Karama programme. Meanwhile, they only announced that the newly added families to the programme were 411,000 families, making the total benefited families 2.9 million but not 3.4 million benefited families as reported. Subsequently, from April until November 2020, only 100,000 and 60,000 newly added families were mentioned in the Egyptian news and studies. Moreover, different numbers were posted during this period on different media sources; Ahram Online posted that the total benefited families reached 3.6 million families at the end of 2020 (Mounir, 2020), While the World Bank reported 3.1 million families (World bank, 2020). The COVID-19 Global Gender Response Tracker has predicted that the benefited families number will reach 3.6 million families by 2021 (UNDP, 2020). Takaful and Karama programme should promote more transparency regarding its operations, giving citizens a chance to give their feedback and enhance their trust and satisfaction.

2) Extended the coverage of beneficiaries of the Takaful and Karama Programme. Takaful and Karama use $87 \%$ of their support to assist the poor, and this percentage covers only $40 \%$ of the total Egyptian poor population (Yassa, 2020). The pandemic severely affected the families that were previously struggling in breadlines and pushed them to be under the poverty line or extreme poverty. The programme should extend the coverage of newly emerged poor or extremely poor households to prevent humanitarian disasters. Also, it should take more flexible criteria to reach those families in need.

\subsection{Children}

Education: 1) Provide e-learning full access to all students. Comfortable/ average families' students did not experience huge changes but from traditional school to distance learning, like other countries students. However, the challenge was about the students with poor households without internet access; by Jan 2020, it was reported that there are 8.69 million Egyptians without phones, and 37.97 million phone users have no access to the internet, which represents half of the population (Kemp, 2020). Also, some families own one smartphone, making it hard for all its members at the educational level to have access to the online materials. Some families cannot afford reliable internet packages for their kids' long study periods. Moreover, many government schools could not provide online teaching to students because of the absence of computers or smart boards. In this regard, the authorities should distribute digital facilities to schools to make online teaching possible and provide smartphones or computers to children from vulnerable families. 2) Support to prevent poor students school dropping out of school. Some low-income families, like informal workers' households, female-headed families, and large-sized households, turned their children into the labor market. In some more extreme cases, they forced their children to beg in the streets to increase their earnings during the pandemic. This requires serious cooperation between schools, parents, and government agencies. Raise 
parents' and students' awareness about the importance of education, identify the students at risk of dropping out of school, provide financial assistance, or consider government assistance programme to cover the families and children, and provide free meals in schools to minimize parents' burden. Meanwhile, schools and the Ministry of Labor and Social Solidarity should take the initiative to identify child laborers and begging kids and help them back to schools. 3) Remediation is necessary to make up for lost learning. A couple of conditions caused different studying gaps among the same grade students that negatively affected students' next academic year and decreased the percentage of passing grades. For example, there is a gap between online learning and televised learning, and the gap between absent students from schools and those who present in class since attending the class has become optional. Thus, schools should provide series of remedial methods to help students study.

Homeless children: Support homeless children. Homeless children are more fragile than homeless adults, and the street environment is extremely harsh to their survival. However, during the crisis, street children did not attract much government attention and support. The Ministry of Social Solidarity should identify those children in the streets and convince them to relocate to the shelter or let them be involved in a social assistance programme. The government should widely cooperate with social workers and NGOs to allow the support to reach those children. Furthermore, care houses or orphanages should set strict and clear regulations that prevent bullying because this is another reason for street children to reject entering care houses and orphanages.

\subsection{Informal Workers and Poor Households}

Should apply electronic and traditional hybrid registration methods. Only 2.5 million workers applied for the emergency grant from around 12.4 million negatively affected workers. Online registration reduced the risk of infection; however, it lacks equality in public access to the internet. As shown previously, almost half of citizens have no internet access or phones, and most of the emergency grant's target groups-informal workers are included in this half who are without internet access due to their poor financial situation. And eventually, the grant did not reach the poorest and neediest informal workers accurately, but non-poor informal workers. Considering both safety and accurate delivery to the neediest people, the best way is to have both online registration and traditional registration. Alongside electronic registration, mobile units with a microphone could be sent to the poorest areas to notify the worker to register. Meanwhile, recruit more people into the selection process to accelerate the whole working procedure. Moreover, the electronic services need a better update to make them more efficient because some people found it difficult to submit their applications or inquiries.

Cover more irregular workers in the emergency fund. The whole country had almost 20 million informal workers; among them, only 2.5 million applied for the grant, and in the end, 1.6 million were qualified. The fund was allocated 
to a few irregular workers; however, the COVID-19 crisis was destructive to most informal workers. Thus the authority is supposed to lessen their requirements to cover more workers and help them overcome the crisis.

Speed the delivery of assistance to the vulnerable population. Respond to the sudden crisis, social assistance matters, but the speed of delivery matters more. Egypt was the first country in the region that planned emergency funds for informal workers, but it took 27 days from announcement to first batch workers received the grant, which was considered the longest waiting time in the region (except Syria 64 days). On the contrary, other countries in the region, like Jordan, took 9 days, Tunisia and Palestine took 12 days, Morocco took 15 days (UNICEF, 2020). High-efficiency collaboration between administration agencies would open greenlight for assistance delivery, especially during a sudden crisis.

Establish an informal workers' database. The incomplete data of informal workers, which made it impossible to accurately and fast allocate assistance to the neediest population. Considering equal and fair social assistance for informal workers and efficient response to future shocks, the government should prioritize establishing databank for the informal sectors based on the database funded during the crisis. To encourage informal sector registration, the government could implement friendly and easy policies to encourage informal workers to register, simplify the registration procedure and provide various social insurances, etcetera.

Identify and support micro, small and medium enterprises (SMEs). It is one of the urgent measures that the Egyptian government should take. There are around 2.5 million SMEs in Egypt, representing 75\% of the total employed workforce (Hala El-Said et al., 2014), and these are a strong power for economic growth and generating employment chances. However, 90\% of SMEs are informal (Stephan, 2020), and it is difficult for the government to develop and manage this sector. Also, informal workers cannot obtain social security benefits. Thus, the relevant agencies should take the initiative to identify SME sectors and informal workers to let them register into the system for future management. The beneficiaries of this initiative are not only informal workers but also concerning national development.

Vaccines should be free for all citizens with an accelerated process of vaccination. The Egyptian government's free vaccines are only for healthcare workers and beneficiaries of the Takaful and Karama programme (14 million individuals), but the rest of the citizens need to pay 200 EGP for their two doses of COVID-19 vaccines (Mandour, 2021). Currently, coronavirus cases are sharply increasing in Egypt, while only a small number of citizens have been vaccinated. In this circumstance, The Egyptian government should cover the vaccine cost and accelerate the vaccination process without adding more stress on the citizens and discourage them from being vaccinated. Over 30.5 million persons have a monthly income of around 735 EGP or less. Besides Takaful and Karama programme, there are still 18.3 million Egyptians who will not afford these luxury vaccines. If the government has no ability to pay for all citizens, at least it could pay for the 
poorest people. Furthermore, vaccination services need to be more efficient; some people registered on the online system and received their registration number but have not been appointed to the designated hospital yet for a couple of weeks. Meanwhile, the affiliated hospitals did not provide registration services without further technical support to accelerate or inquire about the appointments.

Our research has highlighted several issues in the Egyptian government's response to the pandemic and presented different recommendations to help the Egyptian government enhance its responses against the covid19 pandemic. Also, we believe that our recommendation will help other developing countries better set efficient strategies against COVID-19 negative social impact.

\section{Conflicts of Interest}

The author declares no conflicts of interest regarding the publication of this paper.

\section{References}

Aees, S. A. (2020). El Mostakbal Donates EGP 5m to Tahya Misr Fund. Daily News Egypt. https://dailynewsegypt.com/2020/07/19/el-mostakbal-donates-egp-5m-to-tahya-misr-f und

Ahram Online (2020). Egypt's SiSi Orders Expansion in E-Learning: Prime Minister. https://english.ahram.org.eg/NewsContent/1/64/371715/Egypt/Politics-/Egypts-Sisi-or ders-expansion-in-elearning-Prime-mi.aspx

Breisinger, C., Raouf, M., Wiebelt, M., Kamaly, A., \& Karara, M. (2020). Impact of COVID-19 on the Egyptian Economy: Economic Sectors, Jobs, and Households. International Food Policy Research Institute. https://doi.org/10.2499/p15738coll2.133764

Egypt Independent (2020). Egypt\#1 Country in Middle East to Support Women during Coronavirus. UN Report.

https://egyptindependent.com/egypt-1-country-in-middle-east-to-support-women-dur ingcoronavirus-un-report/

Egypt Independent (2021). Egypt's Social Solidarity Ministry, EU, and UNDP Sign €6 mn Agreement to Boost Social Safety Nets amid Pandemic.

https://egyptindependent.com/egypts-social-solidarity-ministry-eu-and-undp-sign-e6mnagreement-to-boost-social-safety-nets-amid-pandemic/

Egypt Today (2020a). 2.5 Million Families Benefit from Takaful and Karam Program: Min. https://www.egypttoday.com/Article/1/81927/2-5-million-families-benefit-from-Takaf ul-and-Karama-program

Egypt Today (2020b). Egypt's Unemployment Rate Records 9.6\% in Q2 2020: CAPMAS. https://www.egypttoday.com/Article/3/90916/Egypt-s-unemployment-rate-records-9-6 -in-Q2-2020

Egypt Today (2020c). Social Solidarity Minister Launches Campaign to Save Homeless People.

https://www.egypttoday.com/Article/1/79760/Social-solidarity-minister-launches-cam paign-to-save-homeless-people

El-Said, H., Al-Said, M., \& Zaki, C. (2014). Small and Medium Enterprises Landscape in Egypt: New Facts from a New Dataset. Journal of Business and Economics, 5, 142-161. https://www.researchgate.net/publication/312121368 Small and Medium Enterprises in\%20 Egypt New Facts from a New Dataset 
International Finance Corporation (2020). Case Study: Exploring Client Approaches to Gender-Based Violence Prevention and Response.

https://www.ifc.org/wps/wcm/connect/5eec8f06-55ee-43ba-833a-a5f81427ccfd/Case+St udy+-+TAQA+Egypt.pdf?MOD=AJPERES\&CVID $=\mathrm{nxABJ} 6 \mathrm{u}$

Jr, R. P. (2021). Policy and Institutional Response to COVID-19 in the Middle East and North Africa: Egypt. Brookings Doha Center.

https://www.brookings.edu/wp-content/uploads/2021/01/MENA-Covid-19-Survey-Eg ypt-January-28-2021-1.pdf

Kemp, S. (2020). Digital 2020: Egypt. Datareportal. https://datareportal.com/reports/digital-2020-egypt

Mandour, M. (2021). President Sisi's COVID-19 Divisive Vaccine Strategy. https://en.qantara.de/content/egypt-plays-politics-with-poverty-president-sisis-covid-1 9-divisive-vaccine-strategy

Mounir, S. (2020). 2011-2020: Programmes to Help the Poor in Egypt. https://english.ahram.org.eg/News/397274.aspx

State Information Service (2021). Compendium of the Ministry of Social Solidarity 2020.

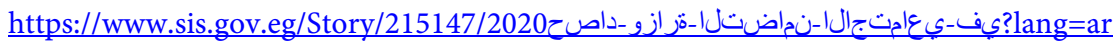

Stephan, M. W. (2020). Views on the Crisis-The Informal Sector. The Egyptian Center for Economic Studies.

http://www.eces.org.eg/cms/NewsUploads/Pdf/2020 4 9-13 8 27informal\%20sector\%20final\%20-\%20English\%20\%20(ebrahim).pdf

UNDP (2020). COVID-19 Global Gender Response Tracker Factsheet: Northern Africa and Western Asia.

https://www.undp.org/content/undp/en/home/librarypage/womens-empowerment/C OVID-19-Global-Gender-Response-Tracker.html

UNICEF (2020). Jordan's National Social Protection Response during COVID-19. https://www.unicef.org/jordan/media/3921/file/Jordan\%27s\%20National\%20SP\%20Re sponse\%20During\%20COVID-\%20UNICEF\%20\%20JSF.pdf

World Bank (2020). Takaful and Karama: A Social Safety Net Project That Promotes Egyptian Women Empowerment and Human Capital. https://www.worldbank.org/en/results/2020/11/17/takaful-and-karama-a-social-safetynet-project-that-promotes-egyptian-women-empowerment-and-human-capital

Yassa, B. (2020). COVID-19 and Social Protection: From Effective Crisis Protection to SelfReliance. International Food Policy Research Institute.

https://egyptssp.ifpri.info/2020/10/05/covid-19-and-social-protection-from-effective-cr isis-protection-to-self-reliance 